\title{
Hygroscopic properties of the Paris urban aerosol in relation to its chemical composition
}

\author{
K. A. Kamilli ${ }^{1, *}$, L. Poulain ${ }^{1}$, A. Held ${ }^{1, *}$, A. Nowak ${ }^{1,{ }^{* *}}$, W. Birmili ${ }^{1}$, and A. Wiedensohler ${ }^{1}$ \\ ${ }^{1}$ Leibniz-Institute for Tropospheric Research, Leipzig, Germany \\ *now at: University of Bayreuth, Bayreuth Center of Ecology and Environmental Research, Bayreuth, Germany \\ ** now at: Physikalisch-Technische Bundesanstalt, Braunschweig, Germany
}

Correspondence to: K. Kamilli (katharina.kamilli@uni-bayreuth.de)

Received: 25 January 2013 - Published in Atmos. Chem. Phys. Discuss.: 31 May 2013

Revised: 22 November 2013 - Accepted: 7 December 2013 - Published: 22 January 2014

\begin{abstract}
Aerosol hygroscopic growth factors and chemical properties were measured as part of the MEGAPOLI "Megacities Plume Case Study" at the urban site Laboratoire d'Hygiène de la Ville de Paris (LHVP) in the city center of Paris from June to August 2009, and from January to February 2010. Descriptive hygroscopic growth factors (DGF) were derived in the diameter range from 25 to $350 \mathrm{~nm}$ at relative humidities of $30,55,75$, and $90 \%$ by applying the summation method on humidified and dry aerosol size distributions measured simultaneously with a humidified differential mobility particle sizer (HDMPS) and a twin differential mobility particle sizer (TDMPS). For $90 \%$ relative humidity, the DGF varied from 1.06 to 1.46 in summer, and from 1.06 to 1.66 in winter. Temporal variations in the observed mean DGF could be well explained with a simple growth model based on the aerosol chemical composition measured by aerosol mass spectrometry (AMS) and black carbon photometry (MAAP). In particular, good agreement was observed when sulfate was the predominant inorganic factor. A clear overestimation of the predicted growth factor was found when the nitrate mass concentration exceeded values of $10 \mu \mathrm{g} \mathrm{m}^{-3}$, e.g., during winter.
\end{abstract}

\section{Introduction}

Aerosol particles are ubiquitous in the atmosphere and play an important role in a variety of fields such as the terrestrial radiation budget, atmospheric chemistry, climate, and human health. Most aerosol-related effects are controlled by particle size, including aerosol dynamical reaction rates, particle de- position, cloud condensation nuclei activation, and light scattering. In the atmosphere, particles take up water well below deliquescence, depending on particle hygroscopicity and ambient relative humidity (Swietlicki et al., 2008). Because the degree of particle hygroscopicity influences ambient particle size and therefore light scattering, hygroscopicity has a direct impact on direct radiative forcing (Haywood and Boucher, 2000). Emphasizing the fact that aerosol water uptake affects both the direct and indirect effect of aerosols, an incomplete understanding of aerosol hygroscopicity has been identified as a major limiting factor in estimating the aerosol climate forcing (IPCC, 2007).

The scientific understanding of the hygroscopic properties of atmospheric particles has improved considerably during the recent years. While the hygroscopic growth of pure soluble ionic species is known quite accurately (Tang and Munkelwitz, 1994; Brechtel and Kreidenweis, 2000), the growth of atmospheric organic matter (Saxena and Hildemann, 1996; Gysel et al., 2004) or complex mixtures of various substances that are typical for the atmosphere are more uncertain.

In the atmosphere, a few inorganic salts constitute the major part of the inorganic aerosol fraction (Heintzenberg, 1989; Putaud et al., 2010). While the impact of the organic fraction on aerosol hygroscopicity has been neglected for a long time, some recent studies have stressed the influence of organic compounds on overall particle hygroscopicity (e.g., Gysel et al., 2007). Organic matter can contribute $20 \%$ to $60 \%$ of the mass of fine particles, depending on location (Chow et al., 1994; Duce et al., 1983; Krivacsy et al., 2001a, b). Consequently, there has been a significant shift in focus 
toward organic hygroscopicity in the last decade. A number of theoretical (e.g., Clegg and Seinfeld, 2006; Topping et al., 2005a, b), laboratory (e.g., Peng et al., 2001; Sjogren et al., 2007; Cruz and Pandis, 2000; Massling et al., 2007) and chamber (e.g., Ansari and Pandis, 2000; Cocker et al., 2001a, b; Duplissy et al., 2008) studies have investigated how the presence of organics affects the hygroscopic properties of the atmospheric aerosol. More in situ measurements with coupled measurements of particle composition and their hygroscopic behavior are needed. Conducting more of those measurements, laboratory studies and hygroscopic growth models can be associated with field measurements.

The standard method for calculating hygroscopic growth from the aerosol chemical composition is based on the water uptake by the individual chemical constituents, the so-called Zdanovskii-Stokes-Robinson mixing rule (ZSR; Stokes and Robinson, 1966). The prediction of water uptake for the inorganic fraction of atmospheric aerosols is usually reliable. In contrast, the vast number of different organic species in the atmosphere (e.g., Saxena and Hildemann, 1996) combined with a limited understanding of organic aerosol hygroscopicity has led to the practice of assigning the water uptake of organics as the particle growth not explained by inorganic constituents (e.g., Malm et al., 2005). This study compares measured and calculated hygroscopic growth factors from field measurements of the aerosol chemical composition and particle number size distributions in the city center of Paris, France.

A limited number of studies (Eichler et al., 2008; Meier et al., 2009; Achtert et al., 2009; Birmili et al., 2009) using the humidified differential mobility particle sizer (HDMPS) system are available. Whereas Meier et al. (2009), Birmili et al. (2009) and Eichler et al. (2008) obtained chemical particle information by impactor measurements, Achtert et al. (2009) were the only with combined HDMPS and aerosol mass spectrometry (AMS) data, but at a rural/suburban site in the North China Plain. Our study is therefore the first one investigating HDMPS size resolved particle growth (cf. HDMPS vs. HTDMA differences in Sect. 3.1) in combination with chemical measurements with high time resolution in a European megacity.

\section{Experimental}

\subsection{The MEGAPOLI field study}

The measurements analyzed in this study were performed under the umbrella of the European FP7 project "Megacities: Emissions, urban, regional and global atmospheric pollution and climate effects, and integrated tools for assessment and mitigation" (MEGAPOLI), investigating interactions of megacities, air quality and climate. MEGAPOLI includes both basic and applied research, and bridges spatial and temporal scales connecting local emissions, air qual- ity and weather with global atmospheric chemistry and climate (Baklanov et al., 2008). Two intensive field campaigns were conducted in the summer of 2009 and the winter of 2010 in Paris, a European megacity of more than 10 million inhabitants. Quantifying sources of primary and secondary aerosol in and around a megacity was a major objective within MEGAPOLI (Baklanov et al., 2008). Our measurements correspond to the atmospheric aerosol obtained under the impact of various diffuse sources found in such a large conurbation. In practice, detailed aerosol and precursor gas measurements were carried out at several urban and suburban sites, and using several mobile laboratories. MEGAPOLI also included airborne observations of the evolution of the megacity plume.

\subsection{Sampling site in Paris}

The measurements were carried out in the backyard of Le laboratoire d'hygiène de la Ville de Paris (LHVP; $48.828^{\circ} \mathrm{N}$, $2.359^{\circ} \mathrm{E}$ ) situated near Place d'Italie in the 13th quarter of Paris, a residential and business district in the south-eastern part of the city of Paris, which has a height of approximately $60 \mathrm{~m}$ a.s.l.

The suite of specialized measurements to characterize the hygroscopic growth properties and the chemical composition included a twin differential mobility particle sizer (TDMPS), a humidifying differential mobility particle sizer (H-DMPS), an aerodynamic particle sizer (APS), a high-resolution timeof-flight aerosol mass spectrometer (HR-ToF-AMS), and a multiangle absorption photometer (MAAP). All instruments were placed inside a laboratory container. Air conditioning was used to stabilize room temperatures, which is crucial for reliable measurements of humidified particle number size distributions. $\mathrm{A} \mathrm{PM}_{10}$ inlet on the container rooftop served as the main inlet for all instruments. A custom-built regenerative adsorption drier (Tuch et al., 2009), which was installed on the rooftop, kept the relative humidity of the sample flow under $25 \%$.

\subsection{Instrumentation}

\subsubsection{Twin differential mobility particle sizer}

The particle number size distribution (PNSD) under dry conditions was measured with a twin differential mobility particle sizer (TDMPS) at a time resolution of $10 \mathrm{~min}$. The particle diameter range was 3-700 nm during the summer campaign and 3-800 $\mathrm{nm}$ in winter. The TDMPS follows the principles outlined in Birmili et al. (1999). Briefly, two Viennatype differential mobility analyzers (Vienna DMA, Winklmayr et al., 1991) and two corresponding condensation particle counters (UCPC 3025 and CPC 3010; TSI Inc., St. Paul, MN, USA) are used in the TDMPS. The particles were charged and brought into charge equilibrium as described by Wiedensohler et al., 2012 (their Table 3 for IFT-TDMPS 
composition). With the aid of additional regenerative diffusion dryers inside the TDMPS, typical conditions were between 5 and $26 \%$ relative humidity (RH) of the aerosol inlet flow, which was continuously monitored. The measured raw mobility concentration was inverted, taking individual CPC collection efficiencies and DMA transfer functions into account, as described by Wiedensohler et al. (2012; Table A2).

\subsubsection{The humidifying differential mobility particle sizer}

Measurements of humidified particle number size distributions were carried out using a humidifying differential mobility particle sizer (HDMPS, Nowak, 2006; Birmili et al., 2009), which has been successfully deployed in several atmospheric field experiments (Eichler et al., 2008; Meier et al., 2009; Achtert et al., 2009; Birmili et al., 2009). The measurement principle is similar to the TDMPS except that the PNSD is recorded in a diameter range from 25 to $800 \mathrm{~nm}$ under controlled relative humidities of $30,55,75$ and $90 \%$.

In a first step, the sample aerosol was humidified to approximately $90 \%$ RH (see Fig. 2; Birmili et al., 2009) in a Nafion pre-humidifier (Model MH-110-12-S, ANSYCO Inc., Karlsruhe, Germany) to ensure that the deliquescence point was exceeded. Because of pre-humidification to $90 \%$ $\mathrm{RH}$, one can assume spherical solution droplets from hygroscopic particles or particles consisting of mixtures of hygroscopic and hydrophobic compounds such as mineral dust (Sjogren et al., 2007).

Subsequently, the aerosol was conditioned to the target humidity by passing the flow through a membrane diffusion dryer (Model MD-110-12F, ANSYCO Inc., Karlsruhe, Germany). It is important to bring the aerosol to the target humidity before entering the neutralizer to guarantee constant RH conditions when reaching the charge equilibrium. The sheath air was also conditioned to reach the target RH before entering the DMA. Finally, the aerosol particles were classified according to their electrical mobility in the DMA and counted with a condensation particle counter (CPC 3010, TSI Inc., St. Paul, MN, USA). To ensure reliable measurements, at least three complete PNSD scans were performed at each humidity step. Thus, a complete cycle through all four target RHs and the selected particle size ranges lasted 2.5 to $3 \mathrm{~h}$, e.g., the data for a chosen diameter at the target $\mathrm{RH}=90 \%$ were available every 150 minutes. After 3 data points followed a gap of approximately $125 \mathrm{~min}$, where the other humidity conditions were recorded. The humidity, temperature and flow conditions inside the HDMPS were constantly monitored using temperature/humidity sensors (HMP230, Vaisala Inc., Helsinki, Finland) and differential pressure transducers. The humidity sensors were calibrated before the campaign with a dew point mirror.

\subsubsection{Chemical composition and black carbon}

In order to measure the chemical composition, we used a high-resolution time-of-flight aerosol mass spectrometer (AMS, Aerodyne Research Inc., Billerica, MA, USA), which uses flash thermal vaporization under high vacuum followed by electron impact ionization and time-of-flight mass analysis (Jayne et al., 2000, Jimenez et al., 2003; Canagaratna et al., 2006). The AMS provides quantitative information of all non-refractory species that are vaporized in a few seconds at a temperature of $600^{\circ} \mathrm{C}$, including organics, sulfate, nitrate, ammonium and non sea-salt chloride. The non-refractory fraction includes the majority of atmospheric components, with the notable exception of black carbon, crustal oxides (dust) and sea salt, which require vaporization at higher temperatures. The AMS mass spectra were analyzed using the data analysis software Squirrel v1.51. (D. Sueper, University of Colorado-Boulder, CO, USA).

Black carbon (BC) was measured using a multiangle absorption photometer (MAAP, type 5012, Thermo Scientific Inc., Franklin, USA), which measures the amount of light that is transmitted through and scattered back from a particleladen glass fiber filter at a wavelength of $637 \mathrm{~nm}$ (Petzold and Schönlinner, 2004). The wavelength of $637 \mathrm{~nm}$ corresponds with the region of the solar spectrum where $\mathrm{BC}$ is the primary absorber; thus, interferences with "brown carbon" and mineral dust are minimized.

In order to obtain a more complete description of the aerosol chemical composition, the AMS and MAAP measurements were combined and averaged to match the time resolution of the hygroscopicity measurements. Particle density was calculated by comparing the time series of dry particle volume derived from the PNSD measurements to the total AMS plus MAAP mass concentration.

\section{Data processing}

\subsection{Determination of hygroscopic growth factors}

A special data reduction method, the so-called summation method (SM, Birmili et al., 2009, Eichler et al., 2008; Achtert et al., 2009), is employed on combined HDMPS/TDMPS data to extract hygroscopic growth factors with high time resolution. The summation method is different from the procedure used to derive hygroscopic growth factors from humidified tandem differential mobility analyzers (HTDMA, e.g., Rader and McMurry, 1986). While in an HTDMA measurement, one or more hygroscopic growth factors representative of different particle fractions are derived directly for a particular preselected particle diameter; the SM yields a number of descriptive hygroscopic growth factors (DGF) for different particle diameters because of the combined HDMPS/TDMPS method. Through the use if these coupled instruments both a dry and a humidified size distribution are 

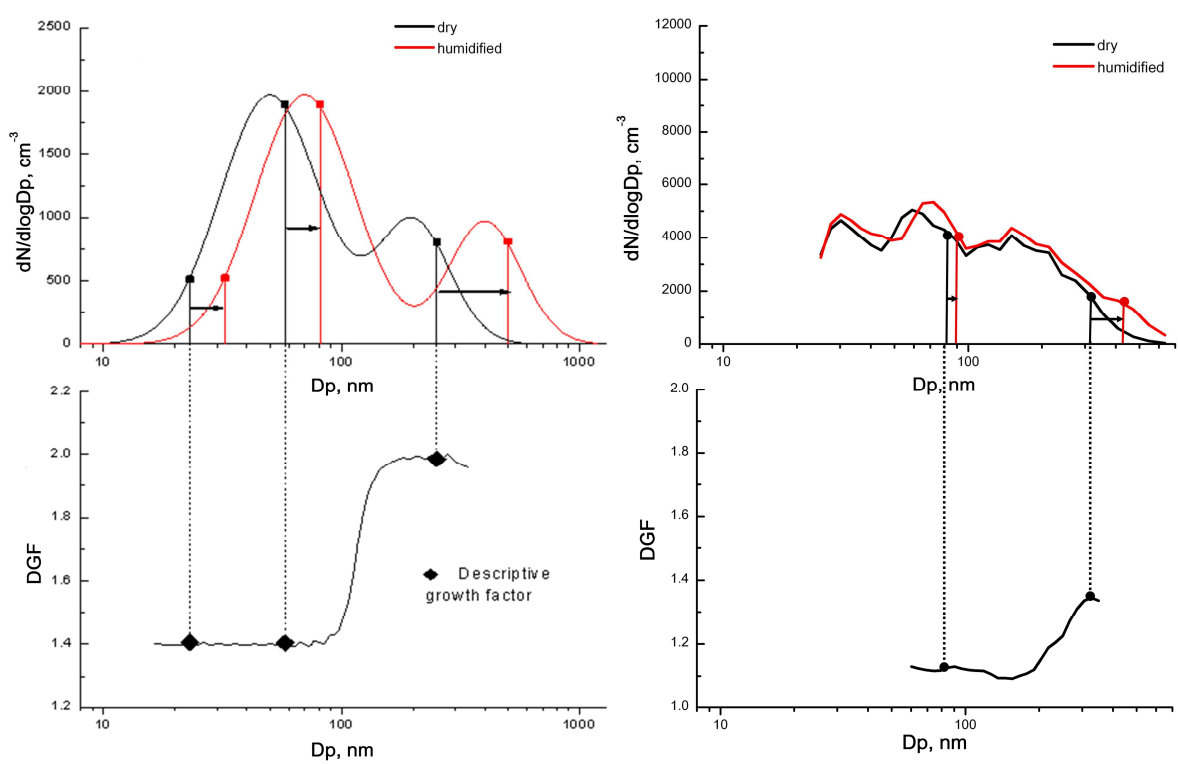

Fig. 1. Dry and humidified size distributions and the corresponding DGF calculated by the summation method. The left panel has been adapted from Nowak (2006). The right panel shows data from the Paris summer campaign.

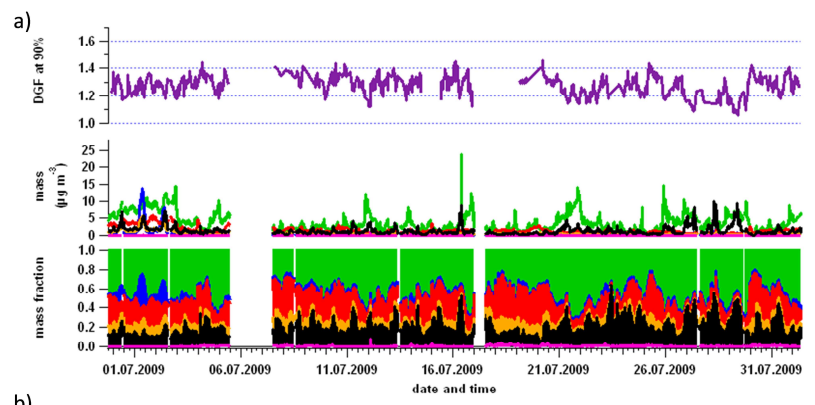

b)

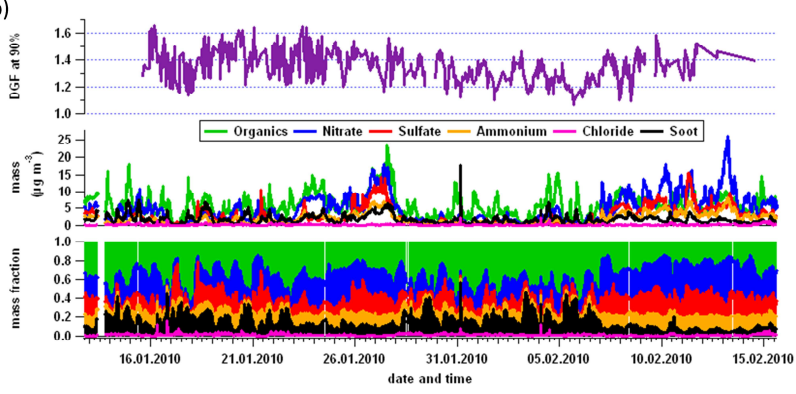

Fig. 2. Time series of the DGF of $285 \mathrm{~nm}$ particles at a RH of $90 \%$ and the particle compounds measured with AMS and MAAP for summer (a) and winter (b).

obtained, which are divided into the same number of segments. The SM assigns every dry segment a humidified segment, beginning with the uppermost segment in every size distribution. So a large number of DGFs are obtained, depending on the number of segments. With this method the DGF value represents an average of all hygroscopic particle fractions at the corresponding particle diameter.
One notable requirement for successful application of the $\mathrm{SM}$ is that the total number under the complete PNSD remains constant with humidification. This implies that no particles are lost or formed during the humidification process. If this is the case, the particle number concentrations measured by the TDMPS and the HDMPS are the same, and the humidification may be considered as a size distribution rearrangement (Birmili et al., 2009). In this study, the total particle number concentration ratio TDMPS/HDMPS was 1.12 on average in summer, and 1.18 in winter for $90 \%$ RH. Due to the departing TDMPS/HDMPS ratio from unity, the computed GFs had to pass a quantile filter. Data were eliminated when the DGF value exceeded the $10 \%$ or $90 \%$ quantiles because one can assume that those extreme DGF values result from extreme values in the TDMPS/HDMPS ratio.

The summation method (Nowak, 2006; Birmili et al., 2009) may be considered as a tool that relates dry and humidified PNSDs. In this method, the dry and humidified cumulative number size distributions are split into 500 disjunct segments with an equivalent number of particles. Note that the segments may be different in diameter width. The SM now allocates the lower boundary diameter of the first segment of the dry PNSD to the lower boundary diameter of the corresponding humidified segment, and continues with the next segments. This process starts from the largest particle diameter and steps towards smaller diameters until the lower end of the PNSD is reached. For each segment, the descriptive hygroscopic growth factor is computed as $\operatorname{DGF}\left(D_{\mathrm{p}(\mathrm{dry})}\right)=$ $D_{\mathrm{p} \text { (wet) }} / D_{\mathrm{p} \text { (dry) }}$. This procedure yields 500 DGF values representative of 500 particle diameter bins distributed over the PNSD size range. As the DGF bins are usually variable, in this study the DGF curve was re-binned onto a fixed grid 
from $25-350 \mathrm{~nm}$ by interpolation. An example of what the dry and humidified size distributions look like is depicted in Fig. 1. The left panel shows theoretical values taken from Nowak (2006). The TDMPS and HDMPS size distributions in the right panel are original data measured during the Paris summer campaign.

One might argue that the segmentation of particle number distributions is not appropriate because it assumes internally mixed particles. H-TDMA studies usually identify an external particle mixture with regard to their hygroscopicity (Swietlicki et al., 2008). The summation method is assumed to be valid as long as changes in overall hygroscopicity, which includes the two sub-aspects external mixture as well as the absolute value of the growth factor, are modest compared to changes in particle diameter. A failure in the SM would be identified by a sharp step in the DGF curve resulting from the allocation of number size distribution segments. There are several arguments against such a failure's relevance in the case of our MEGAPOLI data set:

1. We did not observe sharp steps in any DGF curve resulting from the allocation of number size distribution segments.

2. The overall size-dependent changes in DGF were monotonous, steady, and rather modest during MEGAPOLI, typically increasing from a campaign average 1.1-1.2 at the lower end of the evaluated diameter range around $80 \mathrm{~nm}$ to $1.3-1.4$ at the upper size distribution end (Fig. 6).

3. The urban particle number size distributions during MEGAPOLI were relatively flat, suggesting the presence of an aerosol mixed from multiple sources, and from sources exhibiting wide particle modes.

4. In continental aerosol populations, the particle modes typically exhibit geometric standard deviations of 1.4 and larger. In MEGAPOLI, black carbon was clearly found to exhibit two rather broad modes in the sub- $\mu \mathrm{m}$ range (Healy et al., 2012).

Validation of the summation method has been made by calibration measurements conducted in the laboratory with ammonium sulphate and sodium chloride (see Supplement Figs. S1, S2). The deviation from the model is $5 \%$ for a dry diameter above $50 \mathrm{~nm}$. Growth factor distributions were evaluated above $70 \mathrm{~nm}$, i.e., in a reliable range where the SM can be applied successfully.

Comparisons between HDMPS and HTDMA showed deviations from $5 \%$ for a $\mathrm{RH}$ of $88 \%$ in lab experiments with ammonium sulphate (Supplement Fig. S3). During ambient measurements the deviation between both instruments was up to $20 \%$ (Supplement Fig. S4). The higher deviation in comparison to the lab experiments can be explained by a not yet enhanced HDMPS system at the time of field comparison, which was conducted later on.
Using the summation method, the growth factors were computed for conditions of 55, 75 and $90 \% \mathrm{RH}$ based on the dry PNSD. The $30 \%$ RH measurement of the HDMPS can be considered a dry reference measurement providing results comparable to the TDMPS.

\subsection{Hygroscopic growth model}

The determination of the growth factor based on the Zdanovskii-Stokes-Robinson relation (ZSR) requires knowledge of the volume fractions and the growth factors of the pure substances of mixed aerosol particles. The growth factor is estimated from

$\operatorname{GF}_{\text {mix }}\left(a_{\mathrm{w}}\right) \approx\left(\sum_{i} \varepsilon_{i} g_{i}\left(a_{\mathrm{w}}\right)^{3}\right)^{\frac{1}{3}}$

where $\mathrm{GF}_{\text {mix }}$ is the growth factor of the mixed aerosol particle, $a_{\mathrm{w}}$ is the water activity, $i$ is the number of compounds, $g_{i}$ is the growth factor of compound $i$ in pure form, and $\varepsilon_{i}$ is the volume fraction of compound $I$ in the dry particle. In good approximation, the water activity $a_{\mathrm{w}}$ can be replaced by RH (Gysel et al., 2007) to obtain a functional dependence of $\mathrm{GF}_{\text {mix }}$ on $\mathrm{RH}, \mathrm{GF}_{\text {mix }}(\mathrm{RH})$. The ZSR growth model implies internally-mixed particles and the possibility to independently calculate the water uptake of mixed particles as the sum of the water uptake of each compound.

The AMS measurements provide mass concentrations of ammonium $\left(\mathrm{NH}_{4}\right)$, nitrate $\left(\mathrm{NO}_{3}\right)$, sulfate $\left(\mathrm{SO}_{4}\right)$ and chloride $(\mathrm{Cl})$. Assuming exclusive formation of ammonium salts, ammonium nitrate, ammonium chloride, ammonium sulfate, or ammonium bisulfate may be formed. If the main ammonium salts are $\mathrm{NH}_{4} \mathrm{NO}_{3}, \mathrm{NH}_{4} \mathrm{Cl}$ and $\left(\mathrm{NH}_{4}\right)_{2} \mathrm{SO}_{4}$, the ion charge balance requires

$\frac{m\left(\mathrm{NH}_{4}^{+}\right)}{18}=\frac{m\left(\mathrm{Cl}^{-}\right)}{35}+\frac{m\left(\mathrm{NO}_{3}^{-}\right)}{62}+2 \frac{m\left(\mathrm{SO}_{4}^{2-}\right)}{96}$

where $m$ is the mass concentration of the ions, respectively.

For example, if the main ammonium salts are $\mathrm{NH}_{4} \mathrm{NO}_{3}$, $\mathrm{NH}_{4} \mathrm{Cl}$ and $\mathrm{NH}_{4} \mathrm{HSO}_{4}$, the ion charge balance requires

$\frac{m\left(\mathrm{NH}_{4}^{+}\right)}{18}=\frac{m\left(\mathrm{Cl}^{-}\right)}{35}+\frac{m\left(\mathrm{NO}_{3}^{-}\right)}{62}+\frac{m\left(\mathrm{SO}_{4}^{2-}\right)}{96}$.

In the case of the inorganic salts, the growth factors of the pure substances were obtained from the modified Köhler theory, according to the model by Pitzer (1973). A detailed description can be found in Nowak (2006). For elemental carbon (EC), we assume a growth factor of unity. The hygroscopic growth curve of organics has been determined by a commonly used empirical $\gamma$ model (e.g., Massling et al., 2003; Swietlicki et al., 2000):

$\mathrm{GF}=(1-\mathrm{RH} / 100 \%)^{-\gamma}$,

where $\gamma$ is the model parameter. 


\section{Results}

\subsection{Campaign overview}

The measurements in the city center of Paris started in the evening of 29 June and ended at 1 August 2009 in summer and resumed from 12 January to 15 February 2010 the following winter. Figure 2 gives an overview of the TDMPS/HDMPS and AMS measurements. The time series of the measured DGF shows a clear difference between summer and winter; the values in winter are higher with a maximum value of 1.66 in winter compared to a maximum value of 1.46 in summer. This is consistent with the differences of the aerosol chemical composition. The mass fraction of organic carbon, which reduces the hygroscopic growth factor, is higher in summer than in winter, whereas the fraction of inorganic salts is higher in winter than in summer. Also, one can notice a shift in the mass fractions of nitrate and sulfate. Whereas sulfate is the dominant inorganic salt in summer, the influence of nitrate increases in winter.

\subsection{Correlation between DGF, organic and inorganic mass fractions}

As is obvious in the temporal patterns of the DGF and the organic mass fraction depicted in Figs. $3 \mathrm{a}$ and $4 \mathrm{a}$, and the negative regression between the two variables (Figs. 3b, 4b), the DGF and the organic mass fraction are clearly anticorrelated. With an increasing mass fraction of OC, the DGF decreases. OC was therefore classified as less hydrophilic, and a value of $\gamma=0.075$ (Gysel et al., 2004) was chosen in Eq. (4), which leads to a GF for the organics of 1.19 at $90 \%$ $\mathrm{RH}$. If we evaluate the linear regression presented in Fig. 3b with the equation $y=-0.33 x+1.43$, the growth factor for the OC mass fraction can be determined by setting $x=1$ (purely organic sample). By this computation we arrive at a slightly lower value of $\mathrm{DGF}=1.10$. For the winter campaign the linear regression with the equation $y=-0.36 x+1.47$ yields a value of $D G F=1.11$ (Fig. 4b) for the organic fraction.

Figure $3 \mathrm{c}$ and $\mathrm{d}$ show the correlation of the mass fraction of the inorganic compounds with DGF during the summer campaign. In contrast to the organic fraction, the inorganic compounds have an obvious promoting effect on hygroscopic growth. The time series of the inorganic mass fraction and DGF follow the same pattern, but with differing factors between them. The correlation coefficient $(R)$ is $R=0.79$, indicating a reasonable correlation. For the winter data we obtained a similar correlation (Fig. 4c, d); however, the correlation coefficient $R=0.57$ was lower than in summer.

\subsection{Ion balance}

To initialize the hygroscopic growth model on the basis of chemical composition measurements, knowledge of the ion
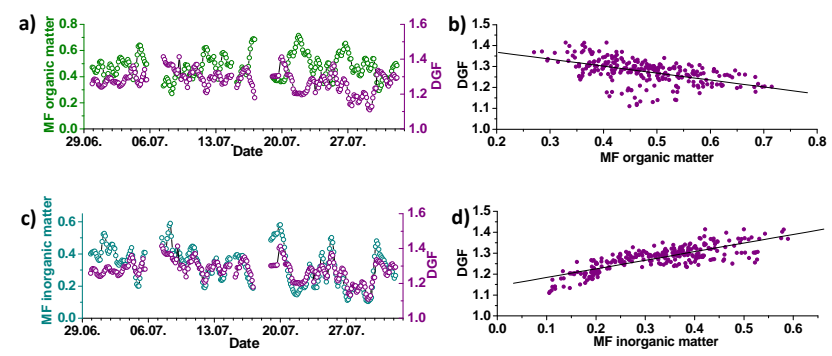

Fig. 3. Correlation between DGF at a RH of $90 \%$ and the mass fraction (MF) of organic matter in summer (a) and the inorganic MF in summer (c) with the corresponding scatter plots (b, d). The linear equation is $y=-0.33 x+1.44$ with a correlation coefficient of -0.52 in (b) and $y=0.41 x+1.14$ with a correlation coefficient of 0.79 in $(\mathbf{d})$.
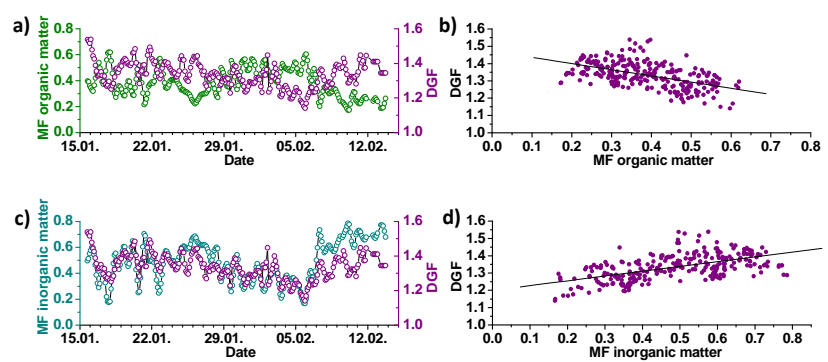

Fig. 4. Correlation between DGF at a RH of $90 \%$ and the MF of organic matter in winter (a) and the inorganic MF in winter (c) with the corresponding scatter plots $(\mathbf{b}, \mathbf{d})$. The linear equation is $y=$ $-0.36 x+1.47$ with a correlation coefficient of -0.52 in (b) and $y=0.28 x+1.2$ with a correlation coefficient of 0.57 in (d).

balance is required. Crippa et al. (2013) calculated the ion charge balance for three MEGAPOLI sites during winter, assuming the presence of ammonium nitrate, ammonium sulfate, and ammonium chloride. In this study, the observed mass concentration of $\mathrm{NH}_{4}^{+}$and the mass concentration of $\mathrm{NH}_{4}^{+}$in ion charge equilibrium calculated from Eqs. (2) and (3) are compared in Fig. 5 to determine whether the ion charges are balanced with ammonium nitrate, ammonium chloride, and ammonium sulfate or ammonium bisulfate. The color of the symbols indicates the measurement date.

As is apparent, in summer the relation between the observed and calculated $\mathrm{NH}_{4}^{+}$concentrations is split into two branches for the calculation with ammonium bisulfate (Fig. 5a). This calculation shows better correlation at the beginning of the campaign until 5 July, and worse correlation for the rest of campaign, shown by a steeper slope of the correlation line deviating from unity. On average, the slope of the regression line between the observed mass concentration of $\mathrm{NH}_{4}^{+}$and the calculated concentration of $\mathrm{NH}_{4}^{+}$in ion charge equilibrium has the value of 1.21. This means that the measured values exceed the calculated ones. For the whole campaign the calculation with ammonium sulfate (Fig. 5b) 

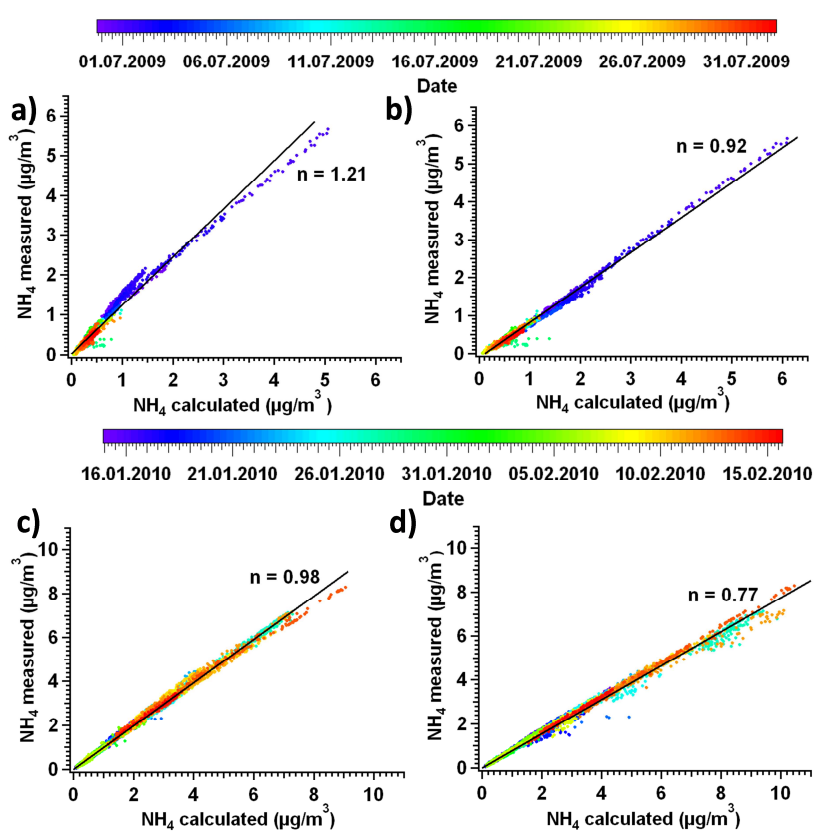

Fig. 5. Comparison of $\mathrm{NH}_{4}$ measured and predicted for ammonium bisulfate (a, c) and ammonium sulfate (b, d) in summer (top) and winter (bottom), where $n$ denotes the slope of the regression line.

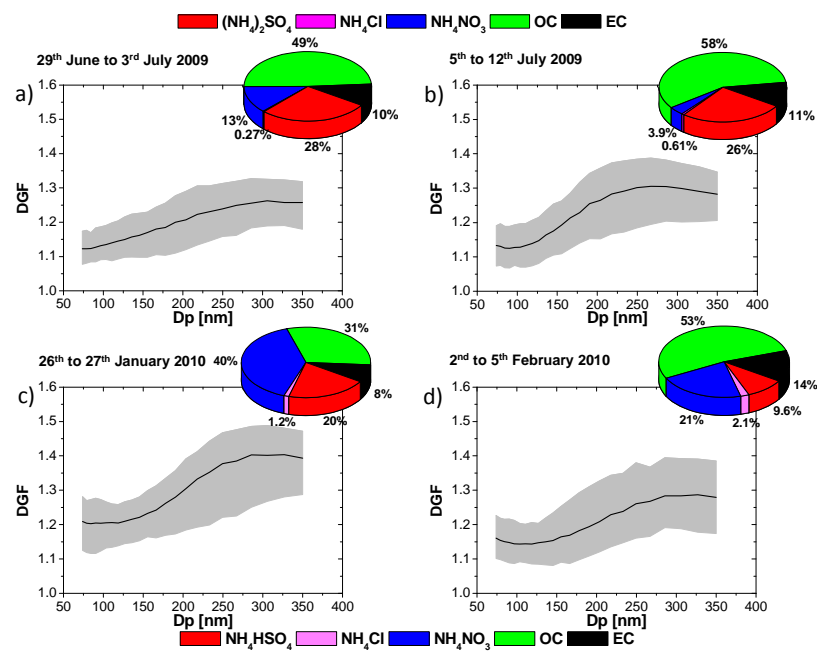

Fig. 6. Growth factor distributions with the mean DGF and 0.1 and 0.9 quantiles for four periods in summer $(\mathbf{a}, \mathbf{b})$ and winter $(\mathbf{c}, \mathbf{d})$ obtained by TDMPS/HDMPS measurements at a RH of $90 \%$. The pie charts show the corresponding volume fractions of the main aerosol compounds.

fits the observations best. The correlation line has a slope of $n=0.92$, which means that on average there is only an $8 \%$ deviation from perfect charge equilibrium.

In winter (Fig. 5c, d), there is no evident separation of certain time periods, neither for the calculation with ammonium bisulfate nor ammonium sulfate. The computation with ammonium bisulfate yields the best results for the whole cam-
Table 1. Overview of the density values and growth factors of the pure substances.

\begin{tabular}{llr}
\hline Composition & $\begin{array}{l}\text { density } \\
{\left[\mathrm{g} \mathrm{cm}^{-3}\right]}\end{array}$ & $\begin{array}{r}\text { GF for 90\% RH } \\
\text { and 285 nm }\end{array}$ \\
\hline $\mathrm{NH}_{4} \mathrm{NO}_{3}$ & 1.73 (Lide, 1993-1994) & 1.71 \\
$\left(\mathrm{NH}_{4}\right)_{2} \mathrm{SO}_{4}$ & 1.77 (Meyer et al., 2009) & 1.66 \\
$\mathrm{NH}_{4} \mathrm{HSO}_{4}$ & 1.78 (Lide, 1993-1994) & 1.67 \\
$\mathrm{EC}$ & 2 (Seinfeld and Pandis, 2006) & 1 \\
$\mathrm{OC}$ & 1.5 (Kostenidou et al., 2007; & 1.19 \\
& Gysel et al., 2004) \\
\hline
\end{tabular}

paign. For ammonium bisulfate, a slope of 0.98 indicates that ion charge equilibrium is reached, while for ammonium sulfate, the slope is 0.77 . Overall, chloride can be neglected because of its vanishingly low amount.

Using the corresponding densities (Table 1), the volume fractions $\varepsilon$ of the particular compounds were determined from the observed mass concentrations of inorganic as well as organic compounds. After the preceding considerations concerning the ion balance, all computations were made with ammonium sulfate data for summer and with ammonium bisulfate data for winter.

\subsection{Case studies of measured and calculated DGFs}

We measured and evaluated the DGF at three different RH conditions, i.e., at $90 \%, 75 \%$ and $55 \%$ RH. All evaluations of growth factors at different relative humidities were made at a diameter of $285 \mathrm{~nm}$. The reason for this is a maximum of the growth factor within the measurement range of the HDMPS directly below a diameter of $300 \mathrm{~nm}$. Thus, this diameter range is most representative for the growth factor of submicron particles. The maximum becomes obvious in Fig. 6. Also, in Fig. 7, where different mass distributions during one sample day are depicted, the peak of aerosol mass is located around the chosen region. The chemical data measured by the AMS represents the $\mathrm{PM}_{1}$ range, as no sizeresolved data were available for both the summer and winter campaigns. Therefore, the computed GF is representative of the submicron aerosol, and a diameter of $285 \mathrm{~nm}$ is the best point of comparison within the diameter range $25-350 \mathrm{~nm}$ for the HDMPS. Additionally, at larger diameters uncertainties associated with the growth factors are higher due to the evaluation method. The averaged DGF at $285 \mathrm{~nm}$ particle diameter are summarized in Table 2 for both the summer and winter campaigns. While the average DGF at $90 \% \mathrm{RH}$ is clearly higher in winter than in summer, the average DGF values at $75 \%$ and $55 \% \mathrm{RH}$ are similar in winter and summer.

In order to investigate the dependence of hygroscopic growth on particle composition in more detail, several periods of constant meteorological conditions were examined. In summer, we determined one period with a strong diurnal 


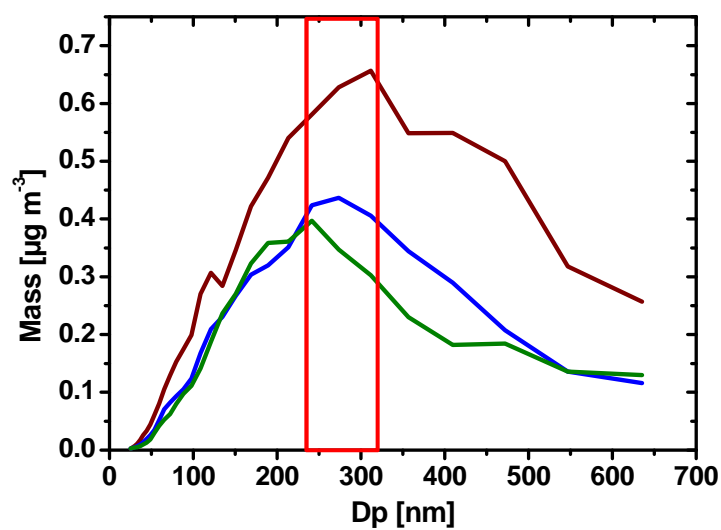

Fig. 7. Mass size distributions of humidified samples at an $\mathrm{RH}$ of $90 \%$ for a sample day during the summer campaign.

Table 2. Measured growth factors on average during summer and winter for $55 \%, 75 \%$, and $90 \%$ relative humidity.

\begin{tabular}{ccc}
\hline $\begin{array}{c}\text { RH } \\
\text { in } \%\end{array}$ & $\begin{array}{c}\text { Average DGF } \\
\text { for 285 nm, summer }\end{array}$ & $\begin{array}{c}\text { Average DGF } \\
\text { for 285 nm, winter }\end{array}$ \\
\hline 55 & 1.05 & 1.04 \\
75 & 1.13 & 1.13 \\
90 & 1.27 & 1.35 \\
\hline
\end{tabular}

variation of nitrate in the beginning of the campaign from 29 June to 3 July, shown in the time series of the AMS measurements in Fig. 2a. In the course of the initial three days the nitrate mass variation between daily minimum and maximum was about $4 \mu \mathrm{g} \mathrm{m}^{-3}$ during the first, $13.3 \mu \mathrm{g} \mathrm{m}^{-3}$ during the second and $6.6 \mu \mathrm{g} \mathrm{m}^{-3}$ during the third day, whereas the nitrate mass varied by $1.8 \mathrm{\mu g} \mathrm{m}^{-3}$ in maximum excluding these first days of the campaign.

In this period, the air masses were advected slowly to Paris, as can be seen in the trajectory plot (Fig. 8a) calculated with the HYSPLIT model provided online by the NOAA Air Resources Laboratory (Draxler and Rolph, 2012; Rolph, 2012). The two backward trajectories arriving at $300 \mathrm{~m}$ and $750 \mathrm{~m}$ above ground level traveled over eastern Germany and northern France $96 \mathrm{~h}$ before arriving in Paris. The upper air layer arriving at $1850 \mathrm{~m}$ above ground level traveled a longer distance above the Atlantic Ocean; however, it did not mix with the other layers and, therefore, did not affect Paris in the lower boundary layer. Due to the slow horizontal transport where the wind speed did not exceed $3 \mathrm{~m} \mathrm{~s}^{-1}$, high total particle as well as black carbon concentrations and a diurnal variation in nitrate developed, which is clearly visible in Fig. 2a. The volume fractions of the aerosol compounds are depicted as pie charts in Fig. 6. Organic carbon is the predominant compound in this period (Fig. 6a) with a volume fraction of $49 \%$. Ammonium sulfate has a volume fraction of $28 \%$, ammonium nitrate of $13 \%$, EC of $10 \%$, and ammonium chloride a negligible fraction of $0.27 \%$. The size dependence of the corresponding DGF at an RH of $90 \%$ is also represented in Fig. 6a, as well as in b-d. Obviously, the DGF increases with increasing particle diameter. In general, due to aging processes one can expect more hydrophilic material in older, larger particles than in fresh, smaller particles. Because the volume fractions of the aerosol compounds are derived from AMS measurements roughly representing $\mathrm{PM}_{1}$, the upper size range of the DGF distribution is crucial for an intercomparison of measured and calculated growth factors.

The second time period of interest lasted from 5 to 12 July 2009, when air masses were brought from over the Atlantic Ocean to Paris (Fig. 8b). The particle mass concentration, which is based on TDMPS data applying a density of $1.6 \mathrm{~g} \mathrm{~cm}^{-3}$, varied from 3 to $18 \mu \mathrm{g} \mathrm{m}^{-3}$, and the concentration of the chemical compounds were lower than in the first period. Also, the change in air mass origin led to a shift in the particle composition (Fig. 6b). In the maritime air masses, precursor gases formed by combustion are less abundant than in the urban aerosol. Therefore, less ammonium nitrate $(3.8 \%)$ was formed, whereas the organic volume fraction $(58 \%)$ increased. All other volume fractions remained roughly the same. One would expect a lower DGF than in the first period, as less hydrophilic material (OC) is more dominant and the volume fraction of hygroscopic inorganic salts is reduced. However, the maximum DGF is slightly higher in the second period than in the first period. One can speculate that the organic fraction of the second period is more hydrophilic than in the first period. When the air masses were brought over the Atlantic Ocean, $\mathrm{NaCl}$ is not considered because a minor contribution of sea salt to $\mathrm{PM}_{1}$ is expected. Moreover, no direct sea-salt measurements in the $\mathrm{PM}_{1}$ range were performed, as the used AMS cannot detect $\mathrm{NaCl}$ under normal operating conditions due to vaporization at $600^{\circ} \mathrm{C}$ under high vacuum.

A third interesting period was found during the winter campaign from 26 to 27 January. Air masses from the east, which crossed densely populated industrial areas in Poland and Germany (Fig. 8c), brought continental aerosol to Paris. Due to the long residence times over these areas, high particle mass concentrations of aged particles were advected. This is also reflected in the aerosol composition with a high volume fraction of ammonium nitrate of $40 \%$ and ammonium bisulfate of $20 \%$. Ammonium chloride volume fractions are slightly higher with $1.2 \%$ but still negligible. The OC volume fraction of $31 \%$ is distinctly lower than in summer. Therefore, the maximum DGF of 1.4 is higher than in summer.

During a fourth period from 2 to 5 February 2010, the air masses coming from the Atlantic were transported over southern France (Fig. 8d). Similar to the second period in summer (Fig. 8b), this period is influenced by maritime air masses. The size dependence of the DGF is approximately the same in these two periods. As in the summer period, the OC volume fraction of more than $50 \%$ is dominant; however, 

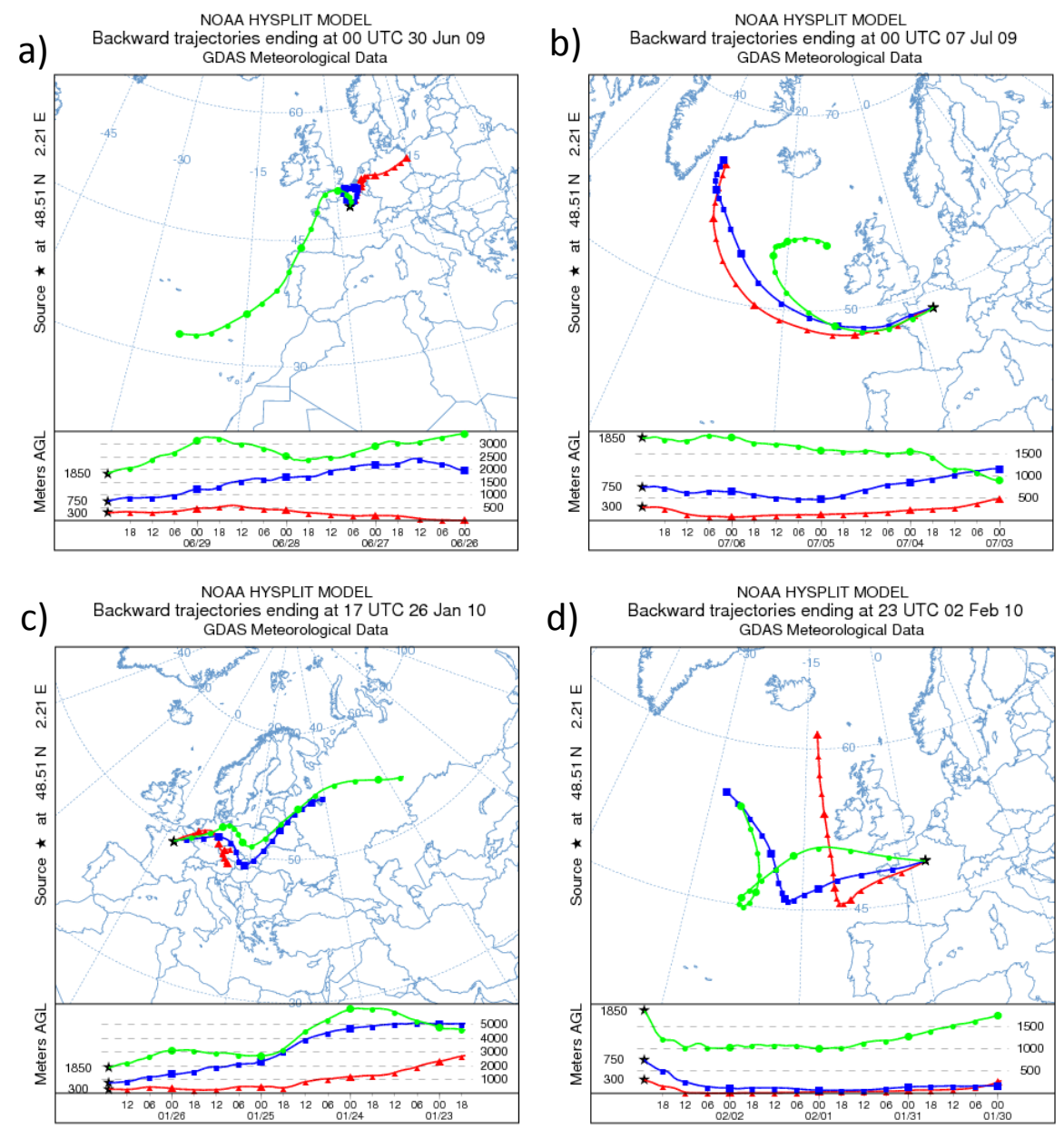

Fig. 8. HYSPLIT trajectories for the 2 periods in summer (top) and winter (bottom).

the inorganic salts are mainly ammonium nitrate $(21 \%)$ and less than $10 \%$ of ammonium bisulfate.

Overall, the absolute values and the size dependence of the DGF do not show pronounced variations even if the chemical composition and the air mass origin are quite variable. Part of the reason for the small variability of the DFG may be due to the averaging over extended time periods, which may reduce the differences between the four selected periods.

\subsection{Overall statistics of measured and calculated DGFs}

As already mentioned in Sect. 4.4, the first few days of the summer campaign are different from the rest of the campaign. This is also evident in the strongest deviation of the measured and the calculated DGF during this period (Fig. 9a), which has a mean value of $10.2 \%$ for the beginning of the campaign and $5.4 \%$ when excluding this period. Therefore, the rest of the time series agrees well if one considers the use of a simplified growth model. The correlation coefficient of the two time series of measured DGF and calculated GF at $90 \% \mathrm{RH}$ is 0.66 for the total of the summer campaign (Fig. 9a). The median of the measured DGF has a value of 1.36 and the median of the calculated GF is 1.28. The diurnal nitrate variation and the associated expected variation in the hygroscopic growth factor is indeed well reproduced by the calculated growth factor, but not by the measured DGF. Possible reasons for this discrepancy are either the increased nitrate concentrations or inaccurate assignment of the corresponding ions in the calculation of the growth factor. In the scatter plot of measured DGF and predicted GF (Fig. 9b), the measurements from 29 of June to 3 July 2009 are indicated in red. Removing these data points, the correlation coefficient is $R=0.76$. Overall, the pattern of the two time series is similar, but the absolute values differ. It is remarkable that the measured time series of the DGF show a much higher variability in winter than in summer. The maximum deviation between the measured and the predicted GF is $37.1 \%$ in winter and $27.1 \%$ in summer. Also, the average value of the deviation for the wintertime data is $8.5 \%$, and thus higher than in summer with $6.5 \%$. For the wintertime data, the correlation coefficient is decreased to $R=0.52$ (Fig. 9c). The median of the two time series differs for the 

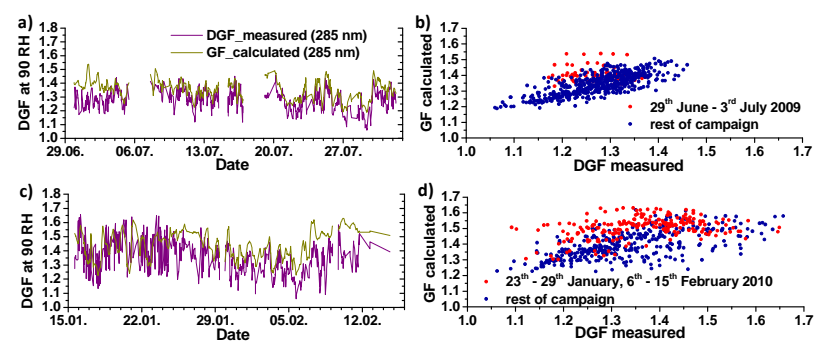

Fig. 9. Time series $(\mathbf{a}, \mathbf{c})$ and scatter plots $(\mathbf{b}, \mathbf{d})$ of the measured DGF and the calculated GF for $285 \mathrm{~nm}$ particles, respectively, computed with the bulk chemical composition measured by the AMS. The correlation coefficient of the two time series are $R=0.66$ (a) and $R=0.52$ (b). Red dots in the scatter plots denote periods under high $\mathrm{NO}_{\mathrm{x}}$ conditions.

whole winter campaign by a value of 0.09 . While the measured DGF is 1.35 , the calculated GF is 1.44. During two winter periods, the calculated GF is distinctly higher than the DGF. During these periods, 23 to 29 January 2010 and 6 to 15 February 2010, the nitrate mass fraction is increased. Just like in summer, the correlation between measured and calculated growth factors improves from $R=0.52$ to $R=0.63$ if these periods (indicated in red in Fig. 9d) are not taken into account.

Previously, McFiggans et al. (2007) obtained reasonable agreement of measured and predicted GF if sulfate was the predominant inorganic compound. Worse agreement was found under nitrate enriched conditions. In these cases the computations overestimated the hygroscopic growth. It was speculated that either the ZSR failed for this case, or that nitrate measured in the AMS was not from ammonium nitrate but from organic nitrates. Similar observations were made by Swietlicki et al. (1999) and Gysel et al. (2002, 2007). These authors reached hygroscopic closure only in the absence of significant nitrate masses. They all concluded that the ZSR could predict the hygroscopic growth with sufficient accuracy; however, nitrate loss based on evaporation within the HTDMA could induce a discrepancy. For a short-term measurement during the MEGAPOLI campaign, the AMS was directly connected to the HDMPS inlet and showed a sudden drop in the nitrate concentration. After connecting the AMS to the standard inlet again, the nitrate concentration was back at the higher level. Therefore, we cannot exclude the possibility of nitrate losses due to evaporation in our system.

The possibility of inaccurate assignment of the ions in the GF calculations was evaluated using the Extended Aerosol Inorganics Model (E-AIM, Aerosol Thermodynamics Model, Model 2; Clegg et al., 1998; Carslaw et al., 1995; Massucci et al., 1999; Clegg and Brimblecombe, 2005). The ion pairing scheme was evaluated under the constraint that only ammonium sulfate, ammonium bisulfate and ammonium nitrate may form. To run the model, the mole fractions of the different ions at a specific time were determined at the beginning and end of the campaign when the particle mass exceeded $25 \mu \mathrm{g} \mathrm{m}^{-3}$. Due to the fact that we only obtained one organic mass fraction containing many different organic compounds from the AMS measurements, for the model calculation an artificial organic model compound was created. As a representative model compound, we used the thermodynamic properties of L-malic acid and a molar mass of $250 \mathrm{~g} \mathrm{~mol}^{-1}$.

The result was not in full agreement with the previous assignments. Ammonium sulfate and ammonium bisulfate occurred in parallel. In summer, at the beginning of the campaign the computed mass of ammonium sulfate was two to three times higher than the mass of ammonium bisulfate. This is similar to our original assignment, where charge equilibrium is reached with ammonium sulfate, ammonium nitrate and ammonium chloride for the summer period. However, for the end of the campaign, the AIM model calculation reached ion balance with ammonium bisulfate in absence of ammonium sulfate. This is in contrast to our original assignment. For the winter period, the AIM model results were in better agreement with our original assignment. Although ammonium sulfate and ammonium bisulfate existed in parallel, ammonium bisulfate concentrations were one to two orders of magnitude higher than ammonium sulfate concentrations, which is consistent with ammonium bisulfate as the dominant sulfate compound.

The water uptake not explained by inorganic constituents (Malm et al., 2005) is often assigned to organics. Then, it is possible to compare the growth factor of the unexplained water uptake with the growth factor of organic matter estimated from the empirical $\gamma$ model in Eq. (4) (i.e., 1.19; cf. Table 1), thus evaluating the accuracy of the selected growth factor. By rearranging the ZSR-relation to yield the growth factor for the organic fraction, and applying all the known values for the inorganic constituents, a growth factor for the organic fraction can be determined, for which the DGF and the calculated GF coincide. The computations for this study yielded growth factors even below unity for the organic fraction, which corresponds to shrinkage with humidification. Thus, the discrepancies between measured DGF and calculated GF could not be equated by a lower growth factor for organic compounds. The median growth factor of organics for a relative humidity of $90 \%$ was 1.06 in summer and 0.87 in winter, respectively. In summer, values below unity only occurred in the beginning when the fluctuations in the GF values were strong. In winter the time series for the measured GF fluctuated steadily, so the computed GF for organics reached values below unity more often.

\section{Conclusion}

Aerosol hygroscopicity has been investigated for the inner city of Paris using growth factor measurements by HDMPS/TDMPS. In addition, the ZSR mixing rule was used 
to predict hygroscopic growth factors based on the aerosol chemical composition measured by AMS and MAAP. The temporal evolution of the predicted growth factor coincided reasonably well with the measured descriptive growth factor. However, it should be noted that the predicted GF almost always was higher than the measured DGF.

Possible reasons for the limited agreement between measured and calculated growth factors are

- ambiguous ion balance calculations and, therefore, ZSR mixing rule computations with inaccurately assigned compounds;

- limitations of the summation method;

- evaluation of the descriptive growth factor measurement for a particle diameter of $285 \mathrm{~nm}$ in comparison with growth factor calculations using the chemical composition of $\mathrm{PM}_{1}$; and/or

- evaporation losses of ammonium nitrate.

Despite the fact that the predicted GF was generally slightly higher than the measured DGF, good agreement was observed when sulfate was the predominant inorganic factor. Worse results with a clear overestimation of the predicted growth factors were found when the influence of nitrate became more dominant, e.g., at the beginning of the summer campaign or at the end of the winter campaign.

Overall, the measured and calculated hygroscopic growth factors show little variation during the observation periods in summer and winter. Even under variable meteorological conditions and corresponding changes in the aerosol chemical composition, the growth factors are quite robust. Hygroscopic growth seems to be more dependent on size than on various chemical compositions, which concurs with Dusek et al. (2006).

\section{Supplementary material related to this article is available online at http://www.atmos-chem-phys.net/14/ 737/2014/acp-14-737-2014-supplement.pdf.}

\begin{abstract}
Acknowledgements. The research leading to these results has received funding from the European Union's Seventh Framework Programme FP/2007-2011 within the project MEGAPOLI, grant agreement no. 21252. We thank V. Gros and M. Beekmann for coordination and logistical help, LHVP director Y. Le Moullec for providing the sampling site, and the LHVP technicians for their technical support.
\end{abstract}

Edited by: M. Beekmann

\section{References}

Achtert, P., Birmili, W., Nowak, A., Wehner, B., Wiedensohler, A., Takegawa, N., Kondo, Y., Miyazaki, Y., Hu, M., and Zhu, T.: Hygroscopic growth of tropospheric particle number size distributions over the North China Plain, J. Geophys. Res., 114, 1-12, 2009.

Ansari, A. S. and Pandis, S. N.: Water absorption by secondary organic aerosol and its effect on inorganic aerosol behavior, Environ. Sci. Technol., 34, 71-77, 2000.

Baklanov, A., Lawrence, M., and Pandis, S.: Deliverable 9.1, Copenhagen, Denmark, 150 pp., MEGAPOLI-01-DW-09-03, 2008.

Birmili, W., Stratmann, F., and Wiedensohler, A.: Design of a DMA-based size spectrometer for a large particle size range and stable operation, J. Aerosol Sci., 30, 549-553, 1999.

Birmili, W., Schwirn, K., Nowak, A., Petäjä, T., Joutsensaari, J., Rose, D., Wiedensohler, A., Hämeri, K., Aalto, P., Kulmala, M., and Boy, M.: Measurements of humidified particle number size distributions in a Finnish boreal forest: derivation of hygroscopic particle growth factors, Boreal Environ. Rese., 14, 458480, 2009.

Brechtel, F. and Kreidenweis, S.: Predicting particle critical supersaturation from hygroscopic growth measurements in the humidified TDMA, part I: Theory and sensitivity studies, J. Atmos. Sci., 57, 1854-1871, 2000.

Canagaratna, M., Jayne, J., Jimenez, J. L., Allan, J., Alfarra, M., Zhang, Q., Onasch, T., Drewnick, F., Coe, H., Middlebrook, A., Delia, A.,Williams, L., Trimborn, A., Northway, M., DeCarlo, P., Kolb, C., Davidovits, P., and Worsnop, D.: Chemical and microphysical characterization of ambient aerosols with the aerodyne aerosol mass spectrometer, Wiley InterScience, 2006.

Carslaw, K. S., Clegg, S. L., and Brimblecombe, P.: A thermodynamic model of the system $\mathrm{HCl}-\mathrm{HNO}_{3}-\mathrm{H}_{2} \mathrm{SO}_{4}-\mathrm{H}_{2} \mathrm{O}$, including solubilities of $\mathrm{HBr}$, from $<200 \mathrm{~K}$ to $328 \mathrm{~K}$, J. Phys. Chem., 99, 11557-11574, 1995.

Chow, J. C., Watson, J. G., Fujita, E. M., Lu, Z. Q., Lawson, D. R., and Ashbaugh, L. L.: Temporal and spatial variations of $\mathrm{PM}(2.5)$ and $\mathrm{PM}(10)$ aerosol in the Southern California AirQuality Study, Atmos. Environ., 28, 2061-2080, 1994.

Clegg, S. L. and Brimblecombe, P.: Comment on the "Thermodynamic Dissociation Constant of the Bisulfate Ion from Raman and Ion Interaction Modeling Studies of Aqueous Sulfuric Acid at Low Temperatures" by Knopf et al., J. Phys. Chem. A, 109, 2703-2706, 2005.

Clegg, S. L., Brimblecombe, P., and Wexler, A. S.: Thermodynamic model of the system $\mathrm{H}^{+}-\mathrm{NH}_{4}{ }^{+}-\mathrm{SO}_{4}{ }^{2-}-\mathrm{NO}_{3}{ }^{-}-\mathrm{H}_{2} \mathrm{O}$ at tropospheric temperatures, J. Phys. Chem. A, 102, 2137-2154, http://www.aim.env.uea.ac.uk/aim/aim.php (last access: August 2011), 1998.

Clegg, S. L. and Seinfeld, J. H.: Thermodynamic models of aqueous solutions containing inorganic electrolytes and dicarboxylic acids at 298.15 K. 2. Systems including dissociation equilibria, J. Phys. Chem. A, 110, 5718-5734, 2006.

Cocker, D. R., Clegg, S. L., Flagan, R. C., and Seinfeld, J. H.: The effect of water on gas-particle partitioning of secondary organic aerosol. Part I: alpha-pinene/ozone system, Atmos. Environ., 35, 6049-6072, 2001a.

Cocker, D. R., Mader, B. T., Kalberer, M., Flagan, R. C., and Seinfeld, J. H.: The effect of water on gas-particle parti- 
tioning of secondary organic aerosol: II. m-xylene and 1,3,5trimethylbenzene photooxidation systems, Atmos. Environ., 35, 6073-6085, 2001b.

Crippa, M., DeCarlo, P. F., Slowik, J. G., Mohr, C., Heringa, M. F., Chirico, R., Poulain, L., Freutel, F., Sciare, J., Cozic, J., Di Marco, C. F., Elsasser, M., Nicolas, J. B., Marchand, N., Abidi, E., Wiedensohler, A., Drewnick, F., Schneider, J., Borrmann, S., Nemitz, E., Zimmermann, R., Jaffrezo, J.-L., Prévôt, A. S. H., and Baltensperger, U.: Wintertime aerosol chemical composition and source apportionment of the organic fraction in the metropolitan area of Paris, Atmos. Chem. Phys., 13, 961-981, doi:10.5194/acp-13-961-2013, 2013.

Cruz, C. N. and Pandis, S. N.: Deliquescence and hygroscopic growth of mixed inorganic-organic atmospheric aerosol, Environ. Sci. Technol., 34, 4313-4319, 2000.

Draxler, R. R. and Rolph, G. D.: HYSPLIT (HYbrid SingleParticle Lagrangian Integrated Trajectory) Model access via NOAA ARL READY, http://ready.arl.noaa.gov/HYSPLIT.php (last access: July 2010), NOAA Air Resources Laboratory, Silver Spring, MD, 2012.

Duce, R. A., Mohnen, V. A., Zimmerman, P. R., Grosjean, D., Cautreels, W., Chatfield, R., Jaenicke, R., Ogren, J. A., Pellizzari, E. D., and Wallace, G. T.: Organic material in the global troposphere, Rev. Geophys., 21, 921-952, 1983.

Duplissy, J., Gysel, M., Alfarra, M. R., Dommen, J., Metzger, A., Prevot, A. S. H., Weingartner, E., Laaksonen, A., Raatikainen, T., Good, N., Turner, S. F., McFiggans, G., and Baltensperger, U.: Cloud forming potential of secondary organic aerosol under near atmospheric conditions, Geophys. Res. Lett., 35, L03818, doi:10.1029/2007GL031075, 2008.

Dusek, U., Frank, G. P., Hildebrandt, L., Curtius, J., Schneider, J., Walter, S., Chand, D., Drewnick, F., Hings, S., Jung, D., Borrmann, S., and Andreae, M. O.: Size matters more than chemistry for cloud-nucleating ability of aerosol particles, Science, 312, 1375-1378, 2006.

Eichler, H., Cheng, Y. F., Birmili, W., Nowak, A., Wiedensohler, A., Brüggemann, E., Gnauk, T., Herrmann, H., Althausen, D., Ansmann, A., Engelmann, R., Tesche, M., Wendisch, M., Zhang, Y., Hu, M., Liu, S., and Zeng, L. M.: Hygroscopic properties and extinction of aerosol particles at ambient relative humidity in South-Eastern China, Atmos. Environ., 42, 6321-6334, 2008.

Gysel, M., Weingartner, E., and Baltensperger, U.: Hygroscopicity of aerosol particles at low temperatures. 2: theoretical and experimental hygroscopic properties of laboratory generated aerosols, Environ. Sci. Technol., 36, 63-68, 2002.

Gysel, M., Weingartner, E., Nyeki, S., Paulsen, D., Baltensperger, U., Galambos, I., and Kiss, G.: Hygroscopic properties of watersoluble matter and humic-like organics in atmospheric fine aerosol, Atmos. Chem. Phys., 4, 35-50, doi:10.5194/acp-4-352004, 2004.

Gysel, M., Crosier, J., Topping, D. O., Whitehead, J. D., Bower, K. N., Cubison, M. J., Williams, P. I., Flynn, M. J., McFiggans, G. B., and Coe, H.: Closure study between chemical composition and hygroscopic growth of aerosol particles during TORCH2, Atmos. Chem. Phys., 7, 6131-6144, doi:10.5194/acp-7-61312007, 2007.

Haywood, J. and Boucher, O.: Estimates of the direct and indirect radiative forcing due to tropospheric aerosols: A review, Rev. Geophys, 38, 513-543, 2000.
Healy, R. M., Sciare, J., Poulain, L., Kamili, K., Merkel, M., Müller, T., Wiedensohler, A., Eckhardt, S., Stohl, A., Sarda-Estève, R., McGillicuddy, E., O'Connor, I. P., Sodeau, J. R., and Wenger, J. C.: Sources and mixing state of size-resolved elemental carbon particles in a European megacity: Paris, Atmos. Chem. Phys., 12, 1681-1700, doi:10.5194/acp-12-1681-2012, 2012.

Heintzenberg, J.: Fine particles in the global troposphere, A review, Tellus, 41, 149-160., 1989.

IPCC: Intergovernmental Panel on Climate Change, Climate Change 2007: The Scientific Basis, Summary for Policymakers, http://www.ipcc.ch (last access: May 2013), 2007.

Jayne, J., Leard, D., Zhang, X., Davidovits, P., Smith, K., Kolb, C., and Worsnop, D.: Development of an aerosol mass spectrometer for size and composition analysis of submicron particles, Aerosol Sci. Tech., 33, 49-70, 2000.

Jimenez, J., Jayne, J., Shi, Q., Kolb, C., Worsnop, D., Yourshaw, I., Seinfeld, J., Flagan, R., Zhang, X., Smith, K., Morris, J., and Davidovits, P.: Ambient Aerosol Sampling with an Aerosol Mass Spectrometer, J. Geophys. Res.-Atmos., 108, 8425, doi:10.1029/2001JD001213, 2003.

Kostenidou, E., Pathak, R. K., and Pandis, S. N.: An Algorithm for the Cal- culation of Secondary Organic Aerosol Density Combining AMS and SMPS Data, Aerosol Sci. Technol., 41, 10021010, 2007.

Krivacsy, Z., Gelencser, A., Kiss, G., Meszaros, G., Molnar, A., Hoffer, A., Meszaros, T., Sarvari, Z., Temesi, D., Varga, B., Baltensperger, U., Nyeki, S., and Weingartner, E.: Study on the chemical character of water soluble organic compounds in fine atmospheric aerosol at the Jungfraujoch, J. Atmos. Chem., 39, 235-259, 2001a.

Krivacsy, Z., Hoffer, A., Sarvari, Z., Temesi, D., Baltensperger, U., Nyeki, S., Weingartner, E., Kleefeld, S., and Jennings, S. G.: Role of organic and black carbon in the chemical composition of atmospheric aerosol at European background sites, Atmos. Environ., 35, 6233-6244, 2001b.

Lide, D. R.: CRC Handbook of Chemistry and Physics, 74th Edn., Section 4-36, 1993-1994.

Malm, W. C., Day, D. E., Kreidenweis, S. M., Collett, J. L., Carrico, C., McMeeking, G., and Lee, T.: Hygroscopic properties of an organic-laden aerosol, Atmos. Environ., 39, 4969-4982, 2005.

Massling, A., Wiedensohler, A., Busch, B., Neusüß, C., Quinn, P., Bates, T., and Covert, D.: Hygroscopic properties of different aerosol types over the Atlantic and Indian Oceans, Atmos. Chem. Phys., 3, 1377-1397, doi:10.5194/acp-3-1377-2003, 2003.

Massling, A., Leinert, S., Wiedensohler, A., and Covert, D.: Hygroscopic growth of sub-micrometer and one-micrometer aerosol particles measured during ACE-Asia, Atmos. Chem. Phys., 7, 3249-3259, doi:10.5194/acp-7-3249-2007, 2007.

Massucci, M., Clegg, S. L., and Brimblecombe, P.: Equilibrium partial pressures, thermodynamic properties of aqueous and solid phases, and $\mathrm{Cl} 2$ production from aqueous $\mathrm{HCl}$ and $\mathrm{HNO}_{3}$ and their mixtures, J. Phys. Chem. A, 103, 4209-4226, 1999.

McFiggans, G., Alfarra, M. R., Allan, J., Bower, K., Coe, H., Cubison, M., Topping, D., Williams, P., Decesari, S., Facchini, C., and Fuzzi, S.: Simplification of the representation of the organic component of atmospheric particulates, Faraday Discuss., 130, 341-362, 2007.

Meier, J., Wehner, B., Massling, A., Birmili, W., Nowak, A., Gnauk, T., Brüggemann, E., Herrmann, H., Min, H., and Wiedensohler, 
A.: Hygroscopic growth of urban aerosol particles in Beijing (China) during wintertime: a comparison of three experimental methods, Atmos. Chem. Phys., 9, 6865-6880, doi:10.5194/acp9-6865-2009, 2009.

Meyer, N. K., Duplissy, J., Gysel, M., Metzger, A., Dommen, J., Weingartner, E., Alfarra, M. R., Prevot, A. S. H., Fletcher, C., Good, N., McFiggans, G., Jonsson, A. M., Hallquist, M., Baltensperger, U., and Ristovski, Z. D.: Analysis of the hygroscopic and volatile properties of ammonium sulphate seeded and unseeded SOA particles, Atmos. Chem. Phys., 9, 721-732, doi:10.5194/acp-9-721-2009, 2009.

Nowak, A.: Das feuchte Partikelgrößenspektrometer: Eine neue Messmethode zur Bestimmung von Partikelgrößenverteilungen $(<1 \mu \mathrm{m})$ und größenaufgelösten hygroskopischen Wachstumsfaktoren bei definierten Luftfeuchten, Ph.D. thesis, University of Leipzig, Germany, 2006.

Peng, C., Chan, M. N., and Chan, C. K.: The hygroscopic properties of dicarboxylic and multifunctional acids: Measurements and UNIFAC predictions, Environ. Sci. Technol., 35, 4495-4501, 2001.

Petzold, A. and Schönlinner, M.: Multi Angle absorption photometry-a new method for the measurement of aerosol light absorption and atmospheric black carbon, J. Aerosol Sci., 35, 421-441, 2004.

Pitzer, K. S.: Thermodynamics of electrolytes. I. Theoretical basis and general equations, J. Phys. Chem., 77, 268-277, 1973.

Putaud, J.-P., van Dingenen, R., Alastuey, A., Bauer, H., Birmili, W., Cyrys, J., Flentje, H., Fuzzi, S., Gehrig, R., Hansson, H., Harrison, R., Herrmann, H., Hitzenberger, R., Huglin, C., Jones, A., Kasper-Giebl, A., Kiss, G., Kousa, A., Kuhlbusch, T., Loschau, G., Maenhaut, W., Molnar, A., Moreno, T., Pekkanen, J., Perrino, C., Pitz, M., Puxbaum, H., Querol, X., Rodriguez, S., Salma, I., Schwarz, J., Smolik, J., Schneider, J., Spindler, G., ten Brink, H., Tursic, J., Viana, M., Wiedensohler, A., and Raes, F.: A European aerosol phenomenology - 3: Physical and chemical characteristics of particulate matter from 60 rural, urban, and kerbside sites across Europe, Atmos. Environ., 44, 1308-1320, doi:10.1016/j.atmosenv.2009.12.011, 2010.

Rader, D. J. and McMurry, P. H.: Application of the tandem differential mobility analyzer to studies of droplet growth or evaporation, J. Aerosol Sci., 17, 771-787, 1986.

Rolph, G. D.: Real-time Environmental Applications and Display sYstem (READY), http://ready.arl.noaa.gov (last access: July 2010), NOAA Air Resources Laboratory, Silver Spring, MD, 2012.

Saxena, P. and Hildemann, L. M.: Water-soluble organics in atmospheric particles: A critical review of the literature and application of thermodynamics to identify candidate compounds, J. Atmos. Chem., 24, 57-109, 1996.

Sjogren, S., Gysel, M., Weingartner, E., Baltensperger, U., Cubison, M. J., Coe, H., Zardini, A. A., Marcolli, C., Krieger, U. R., and Peter, T.: Hygroscopic growth and water uptake kinetics of twophase aerosol particles consisting of ammonium sulphate, adipic and humic acid mixtures, J. Aerosol Sci., 38, 157-171, 2007.

Stokes, R. H. and Robinson, R. A.: Interactions in aqueous nonelectrolyte solutions: I. Solute-solvent equilibria, J. Phys. Chem., 70, 2126-2131, 1966.
Swietlicki, E., Zhou, J. C., Berg, O. H., Martinsson, B. G., Frank, G., Cederfelt, S.-I., Dusek, U., Berner, A., Birmili, W., Wiedensohler, A., Yuskiewicz, B., and Bower, K. N.: A closure study of sub-micrometer aerosol particle hygroscopic behavior, Atmos. Res., 50, 205-240, 1999.

Swietlicki, E., Zhou, J. C., Covert, D. S., Hämeri, K., Busch, B., Vakeva, M., Dusek, U., Berg, O. H., Wiedensohler, A., Aalto, P., Makela, J., Martinsson, B. G., Papaspiropoulos, G., Mentes, B., Frank, G., and Stratmann, F.: Hygroscopic properties of aerosol particles in the north-eastern Atlantic during ACE-2, Tellus, 52, 201-227, 2000.

Swietlicki, E., Hansson, H.-C., Hämeri, K., Svenningsson, B., Massling, A., McFiggans, G., McMurry, P., Petäjä, T., Tunved, P., Gysel, M. amd Topping, D., Weingartner, E., Baltensperger, U., Rissler, J., Wiedensohler, A., and Kulmala, M.: Hygroscopic properties of submicrometer atmospheric aerosol particles measured with H-TDMA instruments with various environments - a review, Tellus, 60, 432-469, 2008.

Tang, I. and Munkelwitz, H.: Water activities, densities, and refractive indices of aqueous sulfates and sodium nitrate droplets of atmospheric importance, J. Geophys. Res., 99, 18801-18808, 1994.

Topping, D. O., McFiggans, G. B., and Coe, H.: A curved multicomponent aerosol hygroscopicity model framework: Part 1 - Inorganic compounds, Atmos. Chem. Phys., 5, 1205-1222, doi:10.5194/acp-5-1205-2005, 2005a.

Topping, D. O., McFiggans, G. B., and Coe, H.: A curved multicomponent aerosol hygroscopicity model framework: Part 2 - Including organic compounds, Atmos. Chem. Phys., 5, 1223-1242, doi:10.5194/acp-5-1223-2005, 2005 b.

Tuch, T. M., Haudek, A., Müller, T., Nowak, A., Wex, H., and Wiedensohler, A.: Design and performance of an automatic regenerating adsorption aerosol dryer for continuous operation at monitoring sites, Atmos. Meas. Tech., 2, 417-422, doi:10.5194/amt-2-417-2009, 2009.

Wiedensohler, A., Birmili, W., Nowak, A., Sonntag, A., Weinhold, K., Merkel, M., Wehner, B., Tuch, T., Pfeifer, S., Fiebig, M., Fjäraa, A. M., Asmi, E., Sellegri, K., Depuy, R., Venzac, H., Villani, P., Laj, P., Aalto, P., Ogren, J. A., Swietlicki, E., Williams, P., Roldin, P., Quincey, P., Hüglin, C., Fierz-Schmidhauser, R., Gysel, M., Weingartner, E., Riccobono, F., Santos, S., Grüning, C., Faloon, K., Beddows, D., Harrison, R., Monahan, C., Jennings, S. G., O’Dowd, C. D., Marinoni, A., Horn, H.-G., Keck, L., Jiang, J., Scheckman, J., McMurry, P. H., Deng, Z., Zhao, C. S., Moerman, M., Henzing, B., de Leeuw, G., Löschau, G., and Bastian, S.: Mobility particle size spectrometers: harmonization of technical standards and data structure to facilitate high quality long-term observations of atmospheric particle number size distributions, Atmos. Meas. Tech., 5, 657-685, doi:10.5194/amt5-657-2012, 2012.

Winkelmayr, W., Reischl, G. P., Linder, A. O., and Berner, A.: A new electromobility spectrometer for the measurement of aerosol size distributions in the size range from 1 to $1000 \mathrm{~nm}$, J. Aerosol Sci., 22, 289-296, 1991. 